\title{
A Case of Post-reconstruction Dermatitis of the Breast
}

\section{Elia Rosi, Maria Thais Fastame, Antonella Di Cesare and Francesca Prignano*}

Department of Health Sciences, Section of Dermatology, University of Florence, Italy

*Corresponding Author: Francesca Prignano, Department of Health Sciences, Section of Dermatology, University of Florence, Italy.
Received: November 16, 2021

Published: January 10, 2022

(C) All rights are reserved by Francesca

Prignano., et al.

\section{Abstract}

A 51-year-old woman was referred to our dermatologic clinic for the evaluation of a 2-week itchy skin rash. Her medical history was significant for left breast carcinoma, which had been treated whit a unilateral mastectomy and lymph node dissection 3 years prior to this current examination.

Keywords: Dermatitis; Breast; Skin Rash

\section{Case Presentation}

A temporary breast tissue expander had been replaced with a permanent implant several months before the rash onset.

On physical examination erythematous, oedematous, slightly infiltrated plaques with ill-defined borders were localized on and around the breast, adjacent to the surgical scar (Figure 1a). The remaining physical examination was negative. A punch skin biopsy of this area was performed in order to exclude the possibility of cutaneous metastasis. The histological examination showed the presence of capillary ectasias and productive inflammation of the superficial dermis; no neoplastic proliferation was observed. Figure $1 \mathrm{~b}$ shows the clinical picture four weeks after the biopsy in absence of any therapy.

These findings (patient's clinical manifestations and histopathological report), according to our experience, are consistent with a diagnosis of dermatitis following post-mastectomy reconstruction.

This clinical condition is poorly described in literature, even from an epidemiological point of view.
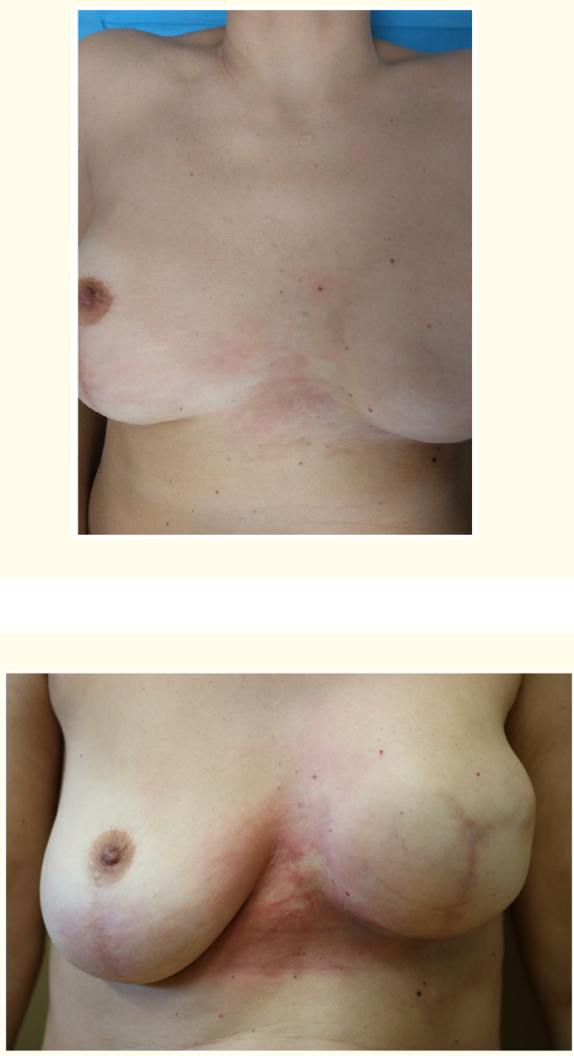
Recently, Rosen and colleagues have defined this entity "postreconstruction dermatitis of the breast", based on a retrospective analysis of 21 cases. The main features of this disease are: variegated clinical presentation, positive clinical response to topical steroid therapy, not clear pathophysiological mechanism involved. The onset of symptoms varies from approximately one month to several years after (and independently of the types of) breast reconstruction [1].

Concerning the pathophysiological mechanism, we agree with the USA group on the prominent role of the vascular stasis following breast reconstruction.

The patient underwent topical steroid therapy after histopathological response with further improvement of her clinical condition.

\section{Conclusion}

We repot this case because of the relative rarity of the clinical picture and in order to differentiate it from the many other dermatitis of this area. It should also be helpful for plastic surgeons because it is strictly linked to breast reconstruction.

\section{Bibliography}

1. Rosen AC., et al. "Post-reconstruction dermatitis of the breast". Journal of Plastic, Reconstructive and Aesthetic Surgery JPRAS 70.10 (2017): 1369-1376.

\section{Assets from publication with us}

- Prompt Acknowledgement after receiving the article

- Thorough Double blinded peer review

- Rapid Publication

- Issue of Publication Certificate

- High visibility of your Published work

Website: www.actascientific.com/

Submit Article: www.actascientific.com/submission.php

Email us: editor@actascientific.com

Contact us: +919182824667

Citation: Francesca Prignano., et al. "A Case of Post-reconstruction Dermatitis of the Breast". Acta Scientific Medical Sciences 6.2 (2022): $50-51$. 